\title{
Mapping 'bio geo-body' of Southeast Asia: strategic differentiation and identification of ethnic identity in Vietnam and Singapore
}

\author{
Tiên-Dung Hà ${ }^{1}$ Mohammad Khamsya Bin Khidzer ${ }^{2}$
}

Accepted: 16 September 2021 / Published online: 27 October 2021

(C) The Author(s) 2021

\begin{abstract}
This research explores how data from population genome projects in Southeast Asia are mobilized for identity formation beyond the lab. We compare two cases, the Vietnamese Genome Project which is funded by a Vietnamese private conglomerate and the Peranakan Genome Project in Singapore, to elucidate how the results from population genomic projects in Vietnam and Singapore are coconstituted with existing political and cultural narratives, as well as with varying notions of 'Chinese-ness'. We find that while scientists in Vietnam use genomics to construct the Vietnamese as genetically independent from what is perceived to be an increasingly dominant Chinese geopolitical power, scientists and participants involved in the Peranakan Genome Project emphasize genomic and cultural mixing which happened between Southern Chinese migrants and the indigenous Malay population historically to distinguish from the rest of the 'Chinese' population in Singapore. The cases illustrate the different ways in which the actors involved in these two genome projects strategically differentiate and negotiate the 'bio geo-body' of the Vietnamese and the Peranakan in relation to the Chinese identity and nationalism, thereby revealing how genomics is intertwined with local and regional histories, culture and politics.
\end{abstract}

Keywords Bio geo-body $\cdot$ Strategic identification and differentiation $\cdot$ Ethnic identity $\cdot$ Postcoloniality $\cdot$ Population genomics $\cdot$ Southeast Asia

Tiên-Dung Hà

tdha@stanford.edu

1 Department of Anthropology, Stanford University, Main Quad, Building 50 450, Serra Mall, Stanford, CA 94305, USA

2 Department of Sociology, University of California San Diego, 9500 Gilman Drive, MC\# 0533, La Jolla, CA 92093-0533, USA 


\section{Introduction}

Consider two different postcolonial states with ongoing genomic projects in Southeast Asia, one in Vietnam and another in Singapore. In December 2018, VinGroup announced a launch of its brand new Institute of Big Data. One of the first tasks of this institute is to conduct research into the Vietnamese genome (Bich Ngoc 2018). The project received \$4.5 USD million funding from VinGroup, a private conglomerate specialized in real estate and hospitality industry, with an aim of sequencing 1000 Vietnamese genomes to chart genome variations of Vietnamese population mainly for biomedical research. VinGroup recruited top Vietnamese scientists both domestic and abroad to join the workforce of this new institute. The Institute of Big Data along with its Vietnamese Genome project is under the direction of a Percey Smith Professor of Mathematics at Yale University, Vũ Hà Văn. In a public interview, Mr. Phạm Nhật Vượng, the founder of VinGroup and the first Vietnamese billionaire, proclaimed that the research into the Vietnamese genome was founded for Vietnamese national pride (Tran 2018). While VinGroup frames their interest in researching the Vietnamese genome as rooted in "national pride," the Vietnamese government recently issued a new policy that provides tax and land incentives for science and technology enterprises (Vietnam Briefing 2019). As such, it is not difficult to speculate that this privately-funded genomic project was highly motivated by a national policy that promotes the growth and development of private industry, more particularly, the privatization of science and tech innovation in Vietnam. One of the recentlypublished articles by VinGroup's scientists makes an important claim about the Vietnamese origin, which suggests "[ancient Vietnamese] population migration from Africa to Asia following the South-to-North route" (Le et al. 2019, p. 1674). The "South-to-North route" indirectly implies that the ancient Vietnamese population does not originate from China, which would follow a North-to-South migration flow.

In 2016, scientists from the Genome Institute of Singapore (GIS), a government supported lab launched SG10K, a national genome project which aimed to catalog genetic diversity and population structures of 10,000 Singaporeans (Bellis et al. 2016). The SG10K study utilized existing Chinese, Malay and Indian racial categories as reference points for clustering cases based on known and novel SNP variants to determine cross racial and within race diversity in Singapore. However, two scientists at Biopolis involved with the study decided to take a different route. They took 2000 samples self-identified Peranakan from the SG10K project and combined the samples with 177 newly collected ones from individuals who identified as Peranakan to create a database for a separate Peranakan Genome Study. In the context of modern-day Singapore and Malaysia, the term Peranakan is used to refer to communities with a mixture of Chinese and Malay heritage. The Peranakans view themselves as culturally distinct from the other major ethnic groups in Singapore-Chinese, Malay and Indian. However, members of the Peranakan community have lamented at being labelled Chinese. This newly legible facet of genomic admixture therefore raises questions on how Peranakan identity 
can be situated within the overarching multicultural frame. given how Peranakans have often been subsumed under the Chinese ethnic category in Singapore.

This paper, therefore, asks how the results from population genomic projects in Vietnam and Singapore are mobilized beyond the lab and co-constituted with political and cultural narratives of the state. In doing so, we explore how certain genomic findings are brought into being in these mapping projects based on already-existing socio-political forces. The paper illustrates how the ethnic identities of the Vietnamese and the Peranakan are negotiated in regard to their historically contested relationships with the Chinese as a dominating power in Southeast Asia. Our paper focuses on "ethnic identity-" making of the Vietnamese and the Peranakan, as "ethnicity" is the term which the scientists involved in these genome projects employed to discuss their studies and findings. We describe the 'strategic calibration' (Benjamin 2009) of population genomics findings in regard to the historical and contemporary geopolitical powers as the strategic mapping of a 'biological geo-body' (or 'bio geo-body'). We find that the VinGroup scientists' use of genomics to strategically construct a Vietnamese bio geo-body as genetically independent from the Chinese. In contrast, scientists and participants involved in the Peranakan Genome Project emphasize genomic and cultural mixing which happened between Southern Chinese migrants and the indigenous Malay population historically to distinguish from the rest of the 'Chinese' population in Singapore. The cases illustrate the different ways in which Chinese-ness is negotiated strategically in two very different contexts as well as on different levels (local vs regional), thereby revealing how genomics is intertwined with local and regional histories as well as culture and politics. More broadly, our case studies will show how the genomic mapping of postcolonial ethnic identity is still entangled with the afterlife of colonial powers.

\section{Population genomics and Asian biopolitics}

The paper engages with the rich body of existing literature on the molecularization of racial and ethnic identities (Duster 2005; Reardon 2009; M'Charek 2008; Abu ElHaj 2007; Fullwiley 2007, 2008; Wade et al. 2014). This line of research highlights the constructedness of populations as "branding products" in scientific or biomedical research (Tupasela AND Snell 2015; Tupasela 2017) and the co-constitution of local history, cultural imaginaries and population genetics that makes up race as a "relational object" in practice (M'Charek 2014), as well as "temporally and spatially organized webs of belonging" (Oikkonen 2017, p. 2). Along this line of research, our paper seeks to show how bioscience and identity politics in Southeast Asia are entangled with geopolitics and with the complexities of national identity as well as colonial and post-colonial histories.

In a Books Forum Introduction published in Biosocieties, Nicolas Langlitz (2011) asks whether there is such a thing as Asian biopolitics. He argues that as the concepts biopolitics (1978) and biosociality (2002) originated from the French cases on governance and patient activism respectively, they would "need to be reworked and, if necessary, replaced" (Langlitz 2011, p. 487) when applied in a different context. We position our project as a response to this clarion call and assert that to 
understand the rise of biopolitics in the Asian context, we first need to understand the historical particularities, local situatedness, and state power that shape scientific knowledge claims about population origins and ethnic identity. We also need to pay attention to how the efforts to redefine ethnic identity and belonging in postcolonial states are intertwined with the mapping and marketing of national population genomes (Benjamin 2009) in order to compete regionally and globally within the realm of science and economy.

Genomic projects in Southeast Asia offer vital entry points into the analysis of emergent intersections of contemporary biosciences and postcolonial identities. While the emergence of genomic research in the global South partly stems from scientists in these locations pushing for the inclusion of underrepresented groups in biomedical databases, we also need to attend to how knowledge production in such initiatives is shaped by historical, cultural and political specificities (Fullwiley and Gibbon 2018; Wade 2017; Ong and Chen 2010). While these genomic projects are mainly concerned with studying disease variations for pharmaceutical research, they also elucidate ancestral origins and history of population migration through comparing genome variants within their populations as well as across Asia. The implication is that extant notions of race, ethnicity and nationality become troubled as groups come to terms with new facets of their identity brought forth by population genomics (Whitmarsh 2009; Sung 2010; Liu 2010; Burton 2018).

Our work also seeks to build on the scholarship on "Asian biotech" (Sunder Rajan 2006; Waldby 2009; Ong and Chen 2010; Fischer 2018). An edited volume on "Asian Biotech" (Ong and Chen 2010) comprises a diverse collection of anthropological work that unpacks how different forms of biotechnologies are giving rise to new configurations of Asian (bio)economies and biopower that are shaping the governmentality, sovereignty, identity and bodies in the region. Liu (2010) provides a critical analysis into the making of Taiwanese stem cells through the idea of genetic hybridity to construct Taiwanese national identity that is genetically distinct from the Chinese. Tsai and Lee (2020) also capture Taiwanese nationhood and desire to be biologically distinctive from China in the construction of Taiwan's national biobank as parts of their "imagined future community" (p. 1). Wen-Ching Sung (2010), on the other hand, explores the ways in which Chinese DNA, more particularly only Chinese Han DNA, are co-opted into bio-nation-building projects of China. China's $\$ 9$ billion USD investment in precision medicine also exemplifies "techno-nationalist competitions between U.S. and China" (Au 2020, p. 1).

Other studies also compare how different socio-political perceptions and economic conditions shape the ways scientists in Mainland China and Taiwan define, sample, and interpret genetic findings about their population (Sleeboom-Faulkner 2006). Shirley Sun (2017) explores the historical formations of ethnic categories in Asia, and how populations are now ethnically and racially labeled and categorized amid the forces of genomic science and global pharmaceutical industry. Her analysis highlights that the process of classifying ethnic and racial groups depends less on particular genetic markers or allelic frequencies than on pre-existing political, social and historical construction. This molecularization of ethnic variations can lead to the inclusion and exclusion of certain bodies. Our project is in direct conversation with these social studies in Taiwan and China to further explore the molecularization of 
ethnic identity in Vietnam and Singapore that is deeply-entangled with local histories, ethnic narratives and geo-politics in Southeast Asia.

\section{Strategic mapping biological geo-body of nation states through population genomics}

Our study seeks to highlight the unique geopolitical situation in Southeast Asia to better understand the entanglement between racial epistemologies as legacy of colonialism, and population genomics. In doing so our research takes seriously China's growing influence in the region, which introduces new considerations in the interpretation of population genome data. As we engage with of articulations Chineseness in Vietnam and Singapore, we recognise Chinese nationalism and ethnicity as social constructs. Studies on genomic identity making in China point to the deliberate emphasis on Han Chinese identity at the expense of other ethnic minority identities to create a Chinese bionation (Sung 2010). Such processes in genomic projects, therefore, reflects the conflation between scientific practices with colonial histories as well as contemporary geopolitical narratives. Population genomics has become a technological tool to construct a discourse of identity and geo-body for Vietnamese and Singaporean that have always been contested.

"Geo-body" is a term developed by Thai historian, Winichakul (1997), to highlight how modern cartography produces nations and nationhood spatially. Siam, or Thailand as we know it today, may have existed long before the invention of the modern map. Yet, Winichakul (1997) argues that it was the mapping of Siam coupled with the use of military forces to enforce borders that gave rise to a new geobody that contributed to the discourse of Siam. As such, modern cartography is an "inscriptive device," to use Latour's terminology (1987), which concretized the culture, identity and the land of Siam into a natural entity. This mapping of Siam allowed the Siam regime to claim its sovereign power and identify its nationhood and geo-body. Winichakul proposes a "two-way identification" of nationhood: "positively by some common nature, identity, or interests; negatively by the differences with other nations" (ibid, p. 3). As such, in Siam Mapped Winichakul offers us an account of how the geo-body maps both a territorial boundary with bounded sovereignty and the discourse of national identity as the "We-self" versus the other.

In this paper, we adopt Winichakul's (1997) framing in two ways. First, in the case of Vietnam, we explore how the genomic mapping of populations creates a biological geo-body that allow sovereign states to negatively identify their ethnic identities in relations to the Chinese ethnicity. Secondly, in Singapore we extend Winichakul's (1997) idea of the geo-body to analyze the strategic negotiation of the Peranakan ethnic identity at the intra state level where genomic mapping allows for the interrogation of multicultural state building practices and politics. The biological geo-body offers a new way to understand how geo-body is strategically mapped based on choices of reference population in relation to the colonial and post-colonial histories. In light of this, we explore the strategic ways in which the mapping of population identity in both Vietnamese and Peranakan genomic projects are entangled with the geopolitical contexts and history in Southeast Asia, as China emerges 
as both a regional and global powerhouse. The strategic differentiation between the Vietnamese and the Chinese or the strategic identification of the Peranakan with the Chinese and the indigenous Malay echoes what Ruha Benjamin (2009) argues a form of "strategic calibration" that deliberately map and classify their population genome, and in turn, define their ethnic identity, in tandem with their historically-, politically- and culturally-situated narratives. Contrasting the Vietnamese and Singaporean genomic projects, this paper highlights how actors in these two postcolonial contexts contend with genomic markers of Chinese-ness by practicing strategic differentiation, thereby negotiating and balancing Vietnamese and Peranakan ethnic identity in relation to historical and cultural conceptions of Chinese-ness.

\section{How and why comparing Vietnam and Singapore?}

Vietnam and Singapore provide interesting points of comparison due to their colonial pasts, authoritarian political systems, and dependence upon the globalized market economy. Despite being a tiny island nation, Singapore's economy far surpasses that of Vietnam. The two countries and their people share a history of colonialism by foreign forces and internal political divisions. Singapore fell under British colonial rule from 1819, endured Japanese invasion during the second world war and political separation from Malaysia to gain its own independence in 1965 (Turnbull 2009). Vietnam suffered a violent history of various colonial wars against many foreign invaders, including China, France and America, and a unification between South and North Vietnam to achieve its national independence in 1975 (Pelley 2002; Taylor 2013). Today, Vietnam and Singapore are both modern, sovereign states. Yet, their colonial pasts continue to haunt the very notion of identity in both these Southeast Asian nations. Vietnam's communist government has been striving to construct a national ethnic narrative for the Vietnamese to be historically unified, unique, and independent from the Chinese (Pelley 1998). Singapore's postcolonial multicultural system, an artifact of British colonial rule, developed into a highly racialized and hierarchical system, with the Chinese community dominating the upper echelons of society (Heng and Devan 1992; Purushotam 2000; Chua 2003; Goh 2008).

This research stems from larger projects examining the rise of biotechnology in Southeast Asia conducted by two researchers who are originally from Vietnam and Singapore and are currently undergoing graduate training at US-based institutions. We draw from Charis Thompson's (2010) method of comparative analysis and conduct multi-sited ethnography in Vietnam and Singapore to uncover similarities and differences in the scientific cultures and practices of these two postcolonial states. We interviewed a total of 18 scientists, health professionals, and cultural experts in both Vietnam and Singapore (see "Appendix" for Interview List). We also collected field notes from participant observations at lab meetings and professional networking events. The interviews in Vietnam were conducted by one researcher and the interviews in Singapore were conducted by both researchers. The researchers followed a list of questions for the interview but were flexible enough to pursue areas that they felt would open up new areas related to the main inquiry. The interviews were recorded and later transcribed and independently coded by both 
researchers. The themes from the independent coding stage were then cross checked to ensure that there was some degree of agreement on interpretation for the data between researchers before the analysis began. Our recruitment was based on a purposive sampling in which we reached out and interviewed key scientists involved in the genomic projects as well as community leaders and social scientists of the Peranakan.

In Vietnam, we conducted seven interviews with different scientists and researchers, including five interviews with stem cell scientists, bioinformaticians and data scientists working at VinGrop's Institute of Big Data and VinMec's Stem Cell Research Department. We also obtained interviews with two genome scientists at the Genome Institute of Vietnam, located at the Vietnam Academy of Science and Technology in Hanoi. We also conducted participant observation at the VinGroup's Institute of Big Data, observing daily practices of the scientists, joining them for coffee and lunch breaks, and assisting them with writing and proofreading publications in English. Lastly, we also analyzed scientific publications that were produced by the scientists affiliated with the aforementioned institutions in order to understand the discourse employed by the scientists when making claims about the Vietnamese identity in relation to the Chinese.

In Singapore, we interviewed two researchers working on the SG10K project as well as the Peranakan Genome Project. These researchers in turn pointed us towards other participants of a public forum on the Peranakan identity where they had released preliminary findings on the Peranakan Genome Project. From there we managed to interview a member of the Peranakan Association as well as three of the panelists from the public forum. Two of the panelists are academics who study the history of Peranakans in the region whereas the third panelist is an advocate of Peranakan culture in Singapore. We also conducted another interview with a self-identified Peranakan individual to get a sense of what individuals outside of the association thought about the genome project results. The remainder of our interview sample consists of five interviews with scientist-administrators who are involved with the National Precision Medicine Initiative in Singapore. This was done to better understand the scope of precision medicine and how it generally feeds into prevailing knowledge on race and ethnicity in the multicultural island nation.

\section{Historical contestation between the Vietnamese and the Chinese}

The historical relationship between Vietnam and China has been long contested. Since grade schools, most Vietnamese history textbooks have taught Vietnamese students about the one-thousand-year Chinese domination or colonization over Vietnam ("1000 năm Bắc thuộc"), starting from 111 BC to 905 AD (Le 2012). Throughout the 1000-year Chinese colonization, the Vietnamese history books also recorded many courageous battles of the Vietnamese to take back the country from the Chinese rulers. This history lesson reflects the long-standing perception among the Vietnamese among China as the "tyranny of geography," the big and powerful empire that constantly poses a threat against the existence of its smaller neighbor (Thayer 2002, p. 271). This "China threat" is also not a distant past for Vietnam, but 
a present political concern. In 1979, China invaded northern Vietnam to intervene in Vietnam's invasion of Cambodia (Keyes 2002, p. 1191). In 1988, Vietnam and China's naval forces went into a deadly battle in the Eastern Sea, also known as, South China Sea (Thayer 2002, p. 271). The two countries have been contesting political claims over two islands, Hoàng Sa (Paracel) and Trường Sa (Spratly) in the Eastern Sea ever since (Ong 2020, p. 197). In a meeting with US Defense Secretary Jim Mattis in 2018, President Xi Jinping of China asserted: "[China] cannot lose even one inch of the territory left behind by our ancestors. What is other people's, we do not want at all" (Gibbons-Neff and Myers 2018, cited in Ong 2020, p. 198). This loose articulation of ancestors requires serious unpacking especially since it has profound consequences of who counts as having Chinese ancestors and who don't.

Euro-American historians as well as French colonists have claimed Vietnam as being "merely derivative of China" (Pelley 1998, p. 375). During the French colonial period over Vietnam (1887-1945), The French colonial government depicted Vietnam or the Indochina region as "primitive, benefiting from a civilizing influence from outside" (Chassigneux 1929, cited in Pelley, pp. 374-375). This "civilizing influence" that enlightened Vietnam was China. As a result, to the French, Vietnam's culture was shaped and influenced by China (Pelley 1998, p. 375). Based on other Euro American historical accounts of Vietnam, what we know as Vietnam and China today did not exist 1000 years ago. Put differently, Vietnam and China constantly shift their borders as their dynasties expanded or decayed. A direct passage from a book on Postcolonial Vietnam by historian Patricia Pelley describes:

Had the postcolonial Vietnamese turned exclusively to Chinese sources, the issue of national origins would have been obscured in additional ways. First, on the basis of the work of the Han historian Sima Qian, the entity now known as "Vietnam" did not exist (...) from the perspective of the Han emperors, the Vietnamese were not a distinct people; they were one of the "Hundred Barbarians" or "Southern Barbarians" destined probably to fall under the civilizing spell of the Han. (Pelley 2002, p. 148-149)

Another important historian of the Vietnamese, Keith Taylor, also argues that in the second century BCE, northern Vietnam, or the Red River Plain region, used to be a province of Chinese empires, called Yue, a name later appropriated and translated as "Việt" by the Vietnamese (2013, p. 9). Taylor further refuted the "1000 years Chinese domination cliché" by pointing out that "the idea of "domination" does not accurately express the political, economic and cultural relationship existing at that time between inhabitants of what is now northern Vietnam and dynastic regimes based in what is now China" (p. 35-36). This close "political, economic and cultural" interaction brought to fruition the adoption of classic Chinese (chữ Hán) into Vietnamese literary language and "the Chinese-derived ideographic system" (chữ Nôm) in the Vietnamese vernacular for two millennia (Thompson 2003, p. 119). In the seventeenth century, the European missionaries Romanised "chữ Nôm" to ease the communication and teaching of Christianity to the Vietnamese. It was the French colonial system that later set the Romanised version of "chữ Nôm" as the official language, "Quốc Ngữ," of Vietnam today. Therefore, a majority of the Vietnamese language is borrowed from the Chinese language. 
Vietnamese traditional medicine, particularly Northern medicine (Thuốc Bắc), to the French colonial scholars and administrators, was also influenced by "the thousand-year colonisation" of China in Vietnam, and deeply-rooted in Chinese medical knowledge (Monnais et al. 2011). While the French believed the Vietnamese healers merely imitated Chinese medical knowledge, historian C. Michelle Thompson (ibid, p. 14) shows that the Vietnamese "were equal partners in what was a two-way rather than a one-way exchange" in medical knowledge with the Han Chinese. In the rest of this histography on Vietnamese medicine, the authors argue against these binaries and divisions between Northern vs. Southern medicine or Western vs. Eastern medicine. Rather, they propose a hybridity of medicine, or medical pluralism. This work highlights how the making of Vietnamese national medicine reflects the country's struggle for independence from all the different regimes of colonization and wars, as well as the identity struggles of what constitutes the Vietnamese. More broadly, this medical pluralism also reflects a hybrid modernization of Vietnam. While the hybridity of knowledge and culture is useful in understanding the lived experiences of the Vietnamese, the Vietnamese Communist government has been attempting to construct a narrative that the Vietnamese is independently distinct from the Chinese.

When the Communist government gained control of Northern Vietnam from the French in 1954, Vietnamese postcolonial historians took on an important task of rewriting the Vietnamese history, origin and culture as distinctive and independent from the Chinese. One of the most important narratives for Vietnamese postcolonial writers was to "recontextualize Vietnam within a distinctly Southeast Asian rather than East Asian framework" (Pelley 1998, p. 376). As such, historically the Vietnamese connection with the Chinese has been extensively examined in terms of linguistics and geopolitics, rather than genetics. Our ethnographic data highlights how the recontextualization of the Vietnamese as distinctive from the Chinese is being co-opted into Vietnamese scientific research into the population origin of the Vietnamese.

\section{Vietnamese population genomics: Strategic Differentiation between the Vietnamese and Chinese}

Our fieldwork in Vietnam highlights the strategic differentiation of Vietnamese genetic identity carried out by Vietnamese scientists. VinGroup's scientists recently published a study on the genetic relationship between Vietnamese, Thai and Chinese (Le et al. 2019). This research initially started as an autism study among children which conducted a whole exome sequencing (WES) of 200 parents with autistic children. The researchers recruited and conducted whole genome sequencing (WGS) of an additional 105 healthy Vietnamese-Kinh (KHV) individuals from VinGroup's private hospital, VinMec, in Hanoi. The study sequenced the genome of 305 unrelated Vietnamese-Kinh individuals and identified over 700,000 newly-discovered genetic variants in the population. The study also includes samples of over 600 individuals from nine other Asian countries as well as the African (YRI) and European (CEU) populations from the HUGO PanAsian SNP dataset (Le et al. 2019, p. 1666). The scientists employed a "Bayesian 
clustering algorithm fastSTRUCTURE" (Le et al. 2019, p. 1666) to measure the relatedness of the KHV to other ethnic groups.

The study points out two significant findings related to the origins of the Vietnamese. First, the findings show that Vietnamese along with other South East Asian populations originated from Africa about 44,000 years ago and traveled from South to North route. This contradicts the common belief that Vietnamese population, or Southeast Asian population, was a result of a North-to-South migration flow. In other words, the paper asserted that Southeast Asian populations did not come from East Asia (China). The study also argues that Vietnamese-Kinh population (KHV) is more genetically closer to the Yoruba (YRI) population in West Africa than to the Han Chinese population (CHS) (Saigoneer 2019). The study also discovered that Vietnamese and Thai populations share similar ancestral genomic structure and close evolutionary relationships. In our interview with the lead scientist of this article, he shared with us:

Based on the genomic data, we can infer that the Vietnamese do not originate from the Chinese. Despite the 1000-year Chinese domination, Vietnam still managed to protect our own culture, language and genetic code.

He further elaborated that this finding is both significant and sensitive:

Due to the complex political relationship we still have with China, this kind of statement can be seen as controversial, and hence, we need to be careful in framing our message when we publish the data. But if you think about it, this is significant in a sense that we have always fought the Chinese. If we were the same kind of people, there would be no need for wars to fight back or resist the Chinese.

This interpretation of the genetic distinction between the Vietnamese and Chinese, especially the preservation of Vietnamese "own culture, language and genetic code," reflects a deep sense of Vietnamese nationalism. It is also wellaligned with the long-standing postcolonial struggles of the Communist government to distinguish the Vietnamese from the Chinese (Pelley 1998, p. 375). Not only do the findings establish that the Vietnamese do not originate from China or East Asia, they were also seen as a form of scientific justification for Vietnamese resistance against the Chinese during the 1000 years of Chinese domination. Yet, it is also important to note the scientist's awareness of "the complex political relationship we still have with China" and how this interpretation of the data is deemed as potentially "controversial." In our close reading of their published article, the scientists do not make any explicit claim about the Vietnamese distinction from the Chinese nor do they make any historical or political claims about Vietnamese resilience in the face of China's domination. A peer-reviewed scientific article published in a scientific journal is not a place for Vietnamese scientists to make any nationalistic claims. Even if they could do so, they also recognize the very delicate relationship between Vietnam and China. Not only are the two countries in the midst of heated claims to islands in the South China Sea, Vietnam is also dependent on China for economic investments, as much as China 
relies on Vietnam for other economic and diplomatic projects including the Belt Road Initiatives launched by China to build a network of infrastructures across Asia, Africa and Europe (Le 2018). As such, the Vietnamese scientists adapt a strategic differentiation between the Vietnamese and the Chinese that does not explicitly spell out their nationalistic claims as captured in our interviews. Instead of explicitly refuting the arguments that the Vietnamese originated from China or East Asia, the scientists wrote:

The tree structures [of the Vietnamese genome] show that SEA populations are closer to the YRI and CEU [European] than EA [East Asian] populations. The positions of Asian populations in the tree agree with the South-to-North ordering of their geographical locations. The results from both phylogenetic tree reconstruction and PCA support the hypothesis that a population migration from Africa entered Asia along a South-to-North route. (Le et al. 2019, p. 1672)

"South-to-North route" is repeated four times throughout the article to emphasize an important contradiction against the North-to-South migration flow theory that believes the Vietnamese, and Southeast Asian population, originated from the southward expansion of East Asian populations. We are not interested in evaluating the truth value of this claim. Rather, we want to highlight the conflation between cultural perceptions, nationalistic values, and political complexity embedded in the knowledge claims produced by Vietnamese scientists. The mapping of a biological geo-body of the Vietnamese reflects a form of "genomic sovereignty" (Benjamin 2009) in which the less powerful nations, such as Vietnam, attempt to protect and market their property rights of their own biomaterials, while simultaneously identify the Vietnamese ethnic identity against the Chinese against the background of the military threats of China against Vietnam over their long-standing island disputes in the Eastern Sea (or South China Sea).

\section{Racial hierarchies in multicultural Singapore}

In another Southeast Asian country, Singapore has become one of the most highly developed and cosmopolitan city-states in the world. Singapore's multicultural socio-political landscape has long featured the rigid ethnoracial categories of Chinese, Malay, Indian (and the residual 'Other') inherited from the British colonial administration (Goh 2008). These ethnoracial categories are also socially hierarchized in a society which privileges Chinese 'culture' over that of the Indians and Malays (Heng and Devan 1992). Singapore's founding father, Lee Kuan Yew, made several remarks on the racial superiority of the Chinese (socioeconomic privileges and highly educated) compared to the Malay and Indian groups in Singapore: "I have said this on many previous occasions: that had the mix in Singapore been different, had it been $75 \%$ Indians, 15\% Malays and the rest Chinese, it would not have worked" (Lee 1985). He further emphasized: "If we were 100 percent Chinese, we would do better. But we are not and never will be, so we live with what we have" (Kwang et al. 2015, p. 181). While such explicitly racist articulations rarely occur 
today, there is no mistaking the dominance of the 'Chinese' across multiple spheres of life in Singapore. Moreover, this cultural hegemony continues to be strengthened by efforts that look toward China to re-shape Chinese-ness in Singapore (Tan 2003).

However, within the broader Chinese ethnic group, there exists a prominent subgroup-the Peranakans. An ethnically hybrid group which derives cultural practices from the Chinese and indigenous Malays, the Peranakans inhabit the space in-between the official race categories in Singapore's post-colonial multicultural system (Lee 2009). This state of being in between is not new in Peranakan historical narrative. The Peranakans managed to carve out a position as intermediaries between the British colonial administration and locals, thanks to their local knowledge, business acumen and ability to communicate in English, Malay and Hokkien (Rudolph 1998; Dawis 2015; Teoh 2015). In return, the British protected Peranakan privilege, an arrangement that invited contempt from the rest of the populace especially in a post-independent Singapore energized by anti-colonial sentiments (Lee 2008). The Peranakan community kept a low profile since 1965. Yet a renaissance beginning from the late 1980s has seen growing interest in all things Peranakan in the Singapore public (Dawis 2015). The increased visibility and stature of the Peranakan community and culture has led to serious conversations on the Peranakan identity and where it stands in relation to Chinese-ness. Josephine Chia, a prominent member of the Peranakan community in Singapore has written critical commentaries on how the country's multicultural system tends to subsume Peranakans under the Chinese category (Chia 2018). Chia argues that this form of reductionism is problematic because it ignores the historical, cultural and even physical differences (based on skin complexion) between the Peranakans and the Chinese. The Peranakans are also believed to be different from the average Singaporean Chinese, as they supposedly carry Northern Han Chinese genomic structure, a group that formed the first wave of Chinese migrants to the region in the fifteenth century. Non-Peranakan Singaporean Chinese would not have this genomic marker because their ancestors are believed to be part of the later waves of Chinese immigrants-eighteenth and nineteenth century - who came from the South rather than the North of China (interview with Professor Seng).

These contentions aside, the Peranakan culture maintains considerable presence in public space and imagination. If you visit the National Gallery of Singapore for instance, you will find Violet Oon, a famous celebrity chef who identifies as Peranakan, running the kitchen, dishing out authentic Peranakan fare. The uniform for female flight attendants of Singapore's national carrier Singapore Airlines is the sarong kebaya, a traditional dress that is closely associated with Peranakan culture. These examples highlight crucial instances where Peranakan culture is projected as the national culture to the world. Unlike Vietnam who wishes to culturally, historically and politically distinguish themselves from China, Singapore embraces its Chinese historical connection to build closer ties with an increasingly powerful mainland China. However, this turn to China is tempered by a consideration of the multicultural reality and nationalist sentiments in Singapore. The Peranakan identity and the narrative of the hybrid was therefore selected by the state as the model on which contemporary Singapore identity could be built without necessarily compromising its relationship with China (Montsion and Parasram 2018). 
Amid this ethno-political backdrop lies a state-led effort to build the bioscientific sector in Singapore and establish it as a key driver of the economy (Van Epps 2006). Aside from pumping in billions of dollars into national bioscientific research, the government has also invested heavily in infrastructure and human capital-the Biopolis, medical research centers as well as research universities in Singapore have been recipients of generous grants and Singapore continues to send its promising citizens to educational institutions overseas to build global scientific networks and secure the relevant expertise for future scientific projects (Fischer 2013; Van Epps 2006). While the Peranakan do not necessarily feature in this discourse on value and the bioeconomy, "national science" certainly provided the conditions for the Peranakan Genome Project to emerge.

\section{Singapore Peranakan (PRK) project: strategic identification of genetic hybridity in local and regional politics}

I have always been raised as a Peranakan not a Chinese. So, my consciousness is that of a Peranakan. I was obviously aware of the Chinese being part of my roots though I identified more with the Malay culture... So it won't matter what the genetic analysis will be if I took the test because it's more about what I feel rather than the physiology of my biological makeup. (Josephine Chia, writer and prominent member of the Singapore Peranakan community)

As exemplified in the quote above, the Peranakan's hybrid status once stood out awkwardly in Singapore's Chinese-Malay-Indian-Others (or commonly referred to as CMIO) schema (Chua 2003). Today however, Peranakan hybridity overlaps with state projects of globalization and cosmopolitanism, thereby allowing for the seamless reincorporation of the community into a more flexible body politic (Lee 2009). This does not in any way resolve the tension between the rigid CMIO system and Peranakan hybridity. In fact, it has been argued that the incorporation of Peranakans into the multicultural narrative was carefully orchestrated to draw attention away from contradictions and discontinuities involving the community in Singapore's post-independent history. In their critical examination of the TV series Little Nyonya, a hugely popular, state-sponsored drama production about Peranakan history and life in Singapore, Montsion and Parasram (2018) highlighted the omission of a period in history where non-state sanctioned 'Chinese' identities such as the Peranakan, were suppressed. Teoh (2015) forwards a similar dynamic, claiming that skewed focus on the Nyonya in Peranakan cultural representation is very much in line with the state's intention to "contain multiethnic complexities in the past and domesticated" (p. 67). State sponsored museums and heritage projects present the "uncontroversial realm of the "woman's world", that directs the public's gaze away from "the intense debates over ethnocultural and political loyalties that marked the evolution of Straits Chinese identity in the nineteenth and twentieth centuries" (Teoh 2015 , p. 60). This tumultuous history of the Peranakans in Singapore needs to be brought to the fore to better understand the narratives of identification that emerge from the Peranakan genome project. 
For the Peranakan Genome Project, the scientists set out to explore the extent of genomic admixture among participants who identified as Peranakans. This was achieved using 'reference' Chinese and Malay genomes available from preexisting databases such as the SG10K project which also relied on the ethnic self-identification method (see also Wu et al. 2019). The data could also support historical narratives pertaining to patterns of migration and intermarriage in the region, thereby allowing Peranakans to connect to a fuller picture of their ancestry. In separate interviews with each of the PIs of the Peranakan project, they expressed that the objective of the study was not to establish a 'Peranakan genome' through studying population admixture. Rather, they wished to demonstrate genetic heterogeneity in populations. Ironically, the very reliance on Chinese and Malay reference genomes to ascertain Peranakan admixture reflects a degree of determinism that ignores the socially and politically constructed nature of these ethnic identities. The data would also supplement historical narratives pertaining to patterns of migration and intermarriage in the region, thereby allowing Peranakans to connect to a fuller picture of their ancestry. Regardless, as we intend to show, the meanings attached to the research morph as data from the study travels beyond the lab. For the Peranakans involved in the study, it became clearer that the relation to Chinese-ness is an incredibly complex issue that intersects with the politics of national identity, colonial history, the survival of the community and now genomic information.

Majority had this mix... but a very small percentage there was no trace of Malay blood at all...or there were some people who only had Chinese blood. So what they did was they compared the sample with the local Indian population, local Malay population and local Chinese population, meaning those who had been genetically tested but do not identify as Peranakan and they found differences. That's how they know that there is a group with blood that is different from the local Chinese and different from the local Malays. (Dawn, public relations officer of the Peranakan Association of Singapore)

It is easy to paint the Peranakan genome project as a form of resistance to the rigid racial categories in Singapore. In the context of a growing precision medicine movement, the Chinese, Malay and Indian ethnic categories from the multicultural system are more closely tethered them to a biological base (Ong 2015; Sun 2017), it could be argued that the Peranakan community too are doing the same by highlighting their genetic distinctiveness vis a vis the three major race groups. This assertion of difference through genomics is not unlike the cases examined in Taiwan (Tsai 2010), China (Sung 2010) or Brazil (Kent et al. 2015). Yet, as the quote at the beginning of the section presents, even the assertion of Peranakan-ness as a form of biosociality (Rabinow 2002) is shaky. If Peranakan identity is supposed to hinge on admixture traceable to unions between Malays and Northern Han Chinese in the fifteenth century, how can one explain the absence of genomic admixture in some self-identified Peranakans? In fact, even the very question of a mixed ancestry was contested by some members of the Peranakan community. In an interview with one of the scientists in the research: "Some PRK believes that they are pure Chinese, or 'pure breed' Chinese" (Co P.I. of the PRK Genome project). The presence of such a group was corroborated in 
our interview with Dawn from the Peranakan Association, although she explained that this was a small group within the larger Peranakan community. Regardless, these variegated ways in which the genetically admixed identity is made sense of reveals the complex dynamics of identity that is not quite smoothened with technology.

Moreover, given the remarkable stability of the multicultural system in Singapore, there is skepticism that new information from the Peranakan genome project would disrupt the CMIO status quo:

At the end of the day the Peranakans are not going to make it (the results of the genetic ancestry research) into a Chinese, Malay, Indian, Others + Peranakan. There is no legal or national policy effect. To them it must have meant enough to them that they cooperated with the scientists, and they can find out more about their heritage and find out about it through DNA. (Professor Seng, historian/expert panelist at the Peranakan Identity Forum 2019)

Interestingly, the professor recalled a conversation he had with the president of the Peranakan association, in which the latter downplayed the significance of genetics in delineating Peranakan identity. Thus, while the Peranakans are sometimes invoked as model Singaporeans because of their hybrid heritage, there are perceived limitations to the form as well as extent in which Peranakan identity can be asserted in Singapore society. The professor's remarks reflect the disciplinary tendencies of the multicultural system: Peranakan hybridity is promoted only as far as it aids in the grounding of Singapore Chinese identity against recent waves of Chinese immigrants in Singapore (Montsion and Parasram 2018). Any attempt at mobilizing Peranakan identity for political claims making is seen as incompatible with the multicultural system, with the Peranakans being pigeonholed into the Chinese category. Here, Peranakan identity, Chinese-ness and nation building projects are intertwined in complex ways. Compare the professor's skepticism with the curiosity that some of the participants of the project had about genetic admixture and ancestry, and what it means to some of them:

I always wondered where my roots are because for example my Penang grandmother when she was alive, she used to say that her grandmother was from Thailand and that was surprising to me because it was such a faraway connection. So, we know that we are a very mixed race so to speak. (Dawn)

For Dawn and a few other Peranakan participants of the project who willingly contributed their DNA samples, the genetic ancestry component is important to the understanding of their selves and identities. Dawn was looking to confirm her family history which includes a narrative of origin from parts of Southeast Asia. The Peranakan genome project was thus regarded as a technological platform through which she would be able to strengthen her claim to Peranakan heritage. Despite this, Dawn expressed a kind of flexibility in defining Peranakan identity.

How do we reconcile the tension between culture and genetic ancestry as identity markers? We posit that the Peranakan genome project highlights the complexities that go behind the co-construction of genomic identity; new forms of 
knowledge made legible through science and technology become the subject of contestation in the arena of identity making yet they are folded into a normative understanding of how that identity may be perceived for various reasons. For Dawn and a few other members of the Peranakan Association of Singapore we spoke to, the reasons are quite obviously linked to them being more sensitive to the politics of membership and organizational or cultural survival. A rigid definition of Peranakan identity would only serve to exclude the large pool of Singaporean Chinese who could potentially expand the Peranakan base and sustain the momentum enjoyed by the community since the $90 \mathrm{~s}$.

Here, an emergent genomic identity is strategically calibrated, to use Benjamin's (2009) term, to subtly assert a new dimension of hybridity through genomics within a rigid multicultural system. It is important to note here that the calibration does not just occur at the level of 'scientific' definition but also group level interests to rework their uniquely hybrid ethnicity. It is also subtle because as the historian implied during the interview, it would be 'dangerous' for the group if such information becomes translated into overt political claims; Peranakan genomic hybridity is therefore contained within the realm of science and community level discourse such as the forum. However, genomic identity is also constructed in a way that is accommodative of the growing interest in Peranakan culture. This trend is made clear not just based on our interviews with members of the Peranakan association and academics, but also the literature on Peranakan culture in Singapore (Teoh 2015). It is therefore doubly hybrid, in a sense that Peranakan identity is constructed as also being constitutive of genetic and cultural markers. Genomic identity here is, therefore, packaged in a way that renders it flexible and accommodative to multiple levels of Chineseness, in contrast to the oppositional stance described in the Vietnam genome project. Ironically, while Peranakan identity depends on the idea of genetic and/or cultural hybridity distinct from the Chinese, its survival too is contingent on the unsettling of this 'hard' basis of identification.

\section{Conclusion}

Our research has presented how genomic mapping is co-constituted with local histories, political narratives and geo-politics of Southeast Asia in the making of ethnic identity. The actors involved in the Vietnamese and Peranakan Genome Project strategically differentiate and negotiate the 'bio geo-body' of the Vietnamese and the Peranakan in relation to the Chinese identity and nationalism. The Vietnamese Genome and Peranakan genome projects share some commonalities and differences. While the mapping of a distinct bio geo-body seems more apparent in the Vietnamese Genome Project than that of the Peranakan Genome Project, our comparison demonstrates how bio geo-body can be strategically calibrated at both inter-state (Vietnam vs. China) and intra-state (Chinese Peranakan vs. Singaporean Chinese) levels. Both studies construct a distinct sense of national and ethnic identity. Yet, the politics of representation is different in each project. We first delve into the longstanding contested history between the Vietnamese and the Chinese, more particularly the ongoing military dispute between the two countries over land rights of the 
two islands in the Eastern Sea (or South China Sea). We particularly emphasize the efforts of the Vietnamese government and postcolonial scholars to recontextualize the Vietnamese to be independently distinct from the Chinese, from the historical and linguistic perspectives. Our paper demonstrates a new method in the long-standing efforts of the Vietnamese to differentiate themselves from the Chinese, which now focuses on the genetic or biological level.

In the case of the Vietnamese Genome Project, the 'bio geo-body' of the Vietnamese claims produced by a private conglomerate is two-fold. First, the genetic distinction between the Vietnamese and the Chinese corresponds with the state-controlled postcolonial endeavors to distinguish the Vietnamese from the East Asian origin. Genetic distinction of one racial or ethnic group from another is not unique to the Vietnamese case. While Vietnam is politically independent from China, the Vietnamese genomic distinction claims allow the Vietnamese scientists to justify their resistance against the Chinese in the past and the present. This kind of genetic distinction claims utilize the current borderline between Vietnam and China as a genomic marker to categorize whose genome is counted as Vietnamese or Chinese. The Vietnamese Genome project only includes the Vietnamese-Kinh ethnic group, the major ethnic group in Vietnam making up $86 \%$ of the total population. Even then, the Vietnamese-Kinh samples only includes samples from the North. Moreover, the study excludes the other 53 minority groups that make up the remainder of the population. The exclusion of minority ethnic groups in the Vietnamese genome project further deepens sociopolitical divides underlying dominant proclamations concerning who counts as Vietnamese. The articulation of Vietnamese identity vis a vis the Chinese other can be read as a refraction of the dominant status of the Kinh in Vietnam's socio-political landscape. In other words, the contemporary geo-body of Vietnam which exclusively focuses on the majority Vietnamese ethnic group has been biologized to distinguish the Vietnamese from the Chinese, the latter of which is dominating the economic and political power in the Southeast Asia region and beyond by claiming political rights to "every inch of territory left behind by [Chinese] ancestors." As such, the genomic mapping of a bio geo-body of the Vietnamese reflects the efforts of Vietnam in mapping their territory in the face of a contested geo-politics against China in the Eastern Sea.

Second, we also explore the population uniqueness of the Peranakan in relation to the history of multiculturalism in Singapore. While Singapore brands itself as a multicultural state, the history of nationalism in Singapore projects an effort to emphasize the Chineseness within the Singaporean population. Under Lee Kuan Yew's political project, Chinese were considered to have distinct cultural differences and genetic superiority. As such, despite a multiculturalism framing, there is always racialized discourse. The Peranakan Genome Project seems to be fraught and entangled with the politics of ethnic identity making under a highly racialized multicultural system. While the project highlights the efforts of scientist to expand the scope of multiculturalism to raise awareness of the complex and heterogeneous history of the Singapore population and its different ethnic groups, the data encounters various actors in the community that seek to reshape it to fit certain ideals and imaginations of what Peranakan ethnic identity might be. The genomic hybridity of the Peranakan with an emphasis on the hybridity between 
the Chinese and the indigenous Malay or the Indian echoes this racialized hierarchy in which the Chinese is deemed as the superior. As such, the Peranakan genome is co-constituted, with ideas on culture, history, politics and geography coming into play to map a Singaporean bio geo-body that is hybrid and multicultural with its emphasis on the Chinese-ness. At the time of writing this research, we have yet to see the Peranakan genome project being published. This is somewhat curious, given that the project seemed like it was a finished article in 2019 when we did our field work. We can only speculate that the ideas that the scientists were keen on publicizing and publishing might have encountered some form of pushback which led to it being put on the backburner. Such are the realities of doing science in Singapore.

Finally, the paper also complicates the notion of 'national' science or 'national' project. We argue against the demarcation between 'private' and 'national.' While VinGroup is a private conglomerate, their framing for the conception of the Vietnamese Genome Project is based on the "national pride." This 'national pride' to understand the Vietnamese genome may have also been fueled by a recentlyissued policy by the Vietnamese government that gives tax cuts and land fees reduction to science and technology enterprises. The commonality between the Vietnamese, Peranakan and other population genomic projects is the enlistment or recruitments of participants based on the ground of ancestral origins research to build a biobank of the population which can be later used or sold for biomedical and surveillance purposes. Although beyond the scope of this paper, the comparative biocapital aspects of the Vietnamese and Peranakan Genome Projects are ripe for further exploration.

More broadly, our case studies have shown that the mapping of a postcolonial bio geo-body is never free from the legacies of their colonial power. The efforts to eradicate the Chinese influence in Vietnam did not start when the Vietnamese Communist took over, but when the French colonized the country. The British considered the Peranakan as a political elite, who played an intermediary role between the British and the locals, a status the Peranakan still maintains today in Singapore. As such, to understand the mapping of bio geo-body in postcolonial states, we need to attend to how colonial powers still inform postcolonial thoughts. 


\section{Appendix: The interview list}

\begin{tabular}{|c|c|c|}
\hline Interviewee & Background & Interview date \\
\hline \multicolumn{3}{|l|}{ Vietnam } \\
\hline Scientist A & $\begin{array}{l}\text { Stem cell scientist, VinMec's Stem Cell and Gene } \\
\text { Technolgy Research Institute }\end{array}$ & July 2019 \\
\hline Scientist B & Bioinformatician, VinGroup's Big Data Institute & July 2019 \\
\hline Scientist C & $\begin{array}{l}\text { Genome scientist, Institute of Genome Research, } \\
\text { Vietnam Academy of Science \& Technology }\end{array}$ & July 2019 \\
\hline Scientist D (co-PI) & $\begin{array}{l}\text { Computational biologist, VinMec's Stem Cell and } \\
\text { Gene Technolgy Research Institute }\end{array}$ & July 2019 \\
\hline Scientist E (co-PI) & $\begin{array}{l}\text { Stem cell scientist/Medical doctor, VinMec's Stem } \\
\text { Cell and Gene Technolgy Research Institute }\end{array}$ & July 2019 \\
\hline Scientist F & $\begin{array}{l}\text { Genome scientist, Institute of Genome Research, } \\
\text { Vietnam Academy of Science \& Technology }\end{array}$ & July 2019 \\
\hline Scientist F & Genome scientist, VinGroup's Big Data Institute & July 2019 \\
\hline \multicolumn{3}{|l|}{ Singapore } \\
\hline Scientist A (Co-PI) & Genomic medicine, Cardiology & July 2019 \\
\hline Scientist B & Medical School Administrator, Endocrinology & July 2019 \\
\hline Scientist C & Population Genetics & July 2019 \\
\hline Scientist D & Population Genetics & August 2019 \\
\hline Scientist E (Co-PI) & Population Genetics & September 2019 \\
\hline Scientist F & Administrator, Genomic medicine, Oncology & August 2019 \\
\hline Scientist G & Genomic medicine, Endocrinology & August 2019 \\
\hline Professor Seng & History, Forum panelist & August 2019 \\
\hline Peranakan Expert B & History, Southeast Asian languages, Forum panelist & August 2019 \\
\hline Nyonya Dawn & Peranakan Association Public Relations Officer & August 2019 \\
\hline Nyonya Josephine & Member of Peranakan community, Forum panelist & August 2019 \\
\hline Peranakan community member & Policy Research & September 2019 \\
\hline
\end{tabular}


Acknowledgements We are grateful for the generosity of the genome scientists and researchers in Vietnam and Singapore as well as the Peranankan community members for participating in our research. We are also indebted to the intellectual support from the Race and Biomedicine Beyond the Lab (RaBBL) collective, more particularly the extensive comments and advice of Anne Pollock, Ros Williams, and Vivette García Deister, which was instrumental to the development of the paper. Finally, we are thankful for the constructive feedback and suggestions of three anonymous reviewers who helped improve and refine our paper arguments and structure. The research on which this original material is based has been subject to ethical review at the University of California San Diego and Cornell University. We do not have any competing intellectual or financial interests in the research detailed in the manuscript.

\section{Declarations}

Conflict of interest The manuscript is comprised of original material that is not under review elsewhere, and that the study on which the research is based has been subject to appropriate ethical review. The authors do not have any competing interests.

Open Access This article is licensed under a Creative Commons Attribution 4.0 International License, which permits use, sharing, adaptation, distribution and reproduction in any medium or format, as long as you give appropriate credit to the original author(s) and the source, provide a link to the Creative Commons licence, and indicate if changes were made. The images or other third party material in this article are included in the article's Creative Commons licence, unless indicated otherwise in a credit line to the material. If material is not included in the article's Creative Commons licence and your intended use is not permitted by statutory regulation or exceeds the permitted use, you will need to obtain permission directly from the copyright holder. To view a copy of this licence, visit http://creativecommons.org/licen ses/by/4.0/.

\section{References}

$\mathrm{Au}$, L. 2020. Imagining the public: Anticipatory discourses in China's push for precision medicine. BioSocieties. https://doi.org/10.1057/s41292-020-00205-5.

Bellis, C., I.D. Irwan, C. Wang, W.W. Soon, A. Wilm, C.C. Shih, H.H. Ng, J. Liu, and SG10K Consortium. 2016. Introducing "SG10K": Cataloging genetic diversity and population structures in 10,000 South Asians. Attract. https://www.a-star.edu.sg/docs/librariesprovider5/default-document-library/ publications-press-releases/38-bellis_ashg_2016_approved.pdf. Accessed 12 June 2019.

Benjamin, R. 2009. A lab of their own: Genomic sovereignty as postcolonial science policy. Policy and Society 28 (4): 341-355.

Burton, E.K. 2018. Narrating ethnicity and diversity in Middle Eastern national genome projects. Social Studies of Science 48 (5): 762-786.

Chia, J. 2018, October 7. Commentary: I am Peranakan not Chinese. Channelnews Asia Online. https:// www.channelnewsasia.com/news/commentary/peranakan-chinese-malay-identity-singapore-bicen tennial-10745232. Accepted 20 Aug 2019.

Dawis, A. 2015. Analyzing the Little Nyonya: Portrayal of cultural and gender expectations of Peranakan Chinese life in southeast Asia. China Media Research 11 (1): 68.

El-Haj, N.A. 2007. The genetic reinscription of race. Annual Review of Anthropology 36: 283-300.

Fischer, M.M. 2013. Biopolis: Asian science in the global circuitry. Science, Technology and Society 18 (3): 379-404.

Fischer, M.M. 2018. Theorizing STS from Asia-toward an STS multiscale bioecology framework: A blurred genre manifesto/agenda for an emergent field. East Asian Science, Technology and Society: An International Journal 12 (4): 519-540.

Fullwiley, D. 2007. The molecularization of race: Institutionalizing human difference in pharmacogenetics practice. Science as Culture 16 (1): 1-30.

Fullwiley, D. 2008. The biologistical construction of race: 'Admixture' technology and the new genetic medicine. Social Studies of Science 38 (5): 695-735. 
Fullwiley, D., and S. Gibbon. 2018. Genomics in emerging and developing economies. In Handbook of genomics, health and society, 2nd ed. London: Routledge.

Gibbons-Neff, T., and S.L. Myers. 2018. China won't yield 'even one inch' of South China Sea, Xi Tells Mattis. The New York Times, p. 27.

Goh, D.P. 2008. From colonial pluralism to postcolonial multiculturalism: Race, state formation and the question of cultural diversity in Malaysia and Singapore. Sociology Compass 2 (1): 232-252.

Heng, G., and J. Devan. 1992. State fatherhood: The politics of nationalism, sexuality and race in Singapore. In Nationalisms and sexualities, ed. A. Parker, 343-364. London: Routledge.

Keyes, C. 2002. Presidential Address:" The Peoples of Asia"-Science and Politics in the Classification of Ethnic Groups in Thailand, China, and Vietnam. The Journal of Asian Studies 61 (4): 1163-1203.

Kwang, H.F., W. Fernandez, and S. Tan. 2015. Lee Kuan Yew: The man and his ideas. Singapore: Marshall Cavendish International Asia Pte Ltd.

Langlitz, N. 2011. Is there an Asian biopolitics? BioSocieties 6 (4): 487-500.

Le, H.H. 2012. Pre-colonial Vietnam's development under Sino-Vietnamese cultural and economic interactions. International Studies 27: 91-125.

Le, H. 2018. The Belt and Road Initiative in Vietnam: Challenges and Prospects, Perspective. ISEAS Yusof Ishak Institute 18: 1-7.

Le, V.S., K.T. Tran, H.T. Bui, H.T. Le, C.D. Nguyen, D.H. Do, H.T. Ly, L.T. Pham, L.T. Dao, and L.T. Nguyen. 2019. A Vietnamese human genetic variation database. Human Mutation 40 (10): 1664-1675.

Lee, K.Y. 1985, March 1. Debate on President's Address. https://sprs.parl.gov.sg/search/topic?sitti ngdate $=1-3-1985 \&$ htmlfilename=005_19850301_S0005_T0005. Accessed 17 Nov 2019.

Lee, S.K. 2008. The Peranakan Baba Nyonya culture: Resurgence or disappearance? Sari (ATMA) 26: $161-170$.

Liu, J.A., (2010). Making Taiwanese (stem cells): Identity, genetics, and hybridity. In Asian Biotech: Ethics and communities of fate, 239-262. Durham, NC: Duke University Press.

M'charek, A. 2014. Race, time and folded objects: The HeLa error. Theory, Culture \& Society 31 (6): 29-56.

M'charek, A. 2008. Silent witness, articulate collective: DNA evidence and the inference of visible traits. Bioethics 22 (9): 519-528.

Monnais, L., C.M. Thompson, and A. Wahlberg, eds. 2011. Southern medicine for southern people: Vietnamese medicine in the making. Newcastle upon Tyne: Cambridge Scholars Publishing.

Montsion, J.M., and A. Parasram. 2018. The Little Nyonya and Singapore's national self: Reflections on aesthetics, ethnicity and postcolonial state formation. Postcolonial Studies 21 (2): 154-171.

Bich Ngoc. 2018. Vietnamese conglomerate to spend \$4.5mil on genome sequencing project - VnExpress International. VnExpress International-Latest news, business, travel and analysis from Vietnam. https://e.vnexpress.net/news/news/vietnamese-conglomerate-to-spend-4-5mil-on-genome-seque ncing-project-3850984.html. Accessed 11 April 2020.

Oikkonen, V. 2017. Population genetics and belonging: A cultural analysis of genetic ancestry. Cham: Springer.

Ong, A., and N. Chen. 2010. Introduction to Asian Biotech: Bioeconomies and communities of fate. In Asian Biotech: Ethics \& communities of fate. Durham, NC: Duke University Press.

Ong, A. 2015. Why Singapore trumps Iceland: Gathering genes in the wild. Journal of Cultural Economy 8 (3): 325-341.

Ong, A. 2020. Buoyancy: Blue territorialization of Asian power. In Voluminous states: Sovereignty, materiality, and the territorial imagination, ed. D. Battaglia, 191-203. Durham, NC: Duke University Press.

Pelley, P. 2018. The history of resistance and the resistance to history in post-colonial constructions of the past. In Essays into Vietnamese pasts, 232-245. Ithaca, NY: Cornell University Press.

Pelley, P. 1998. "Barbarians" and "Younger Brothers": The Remaking of Race in Postcolonial Vietnam. Journal of Southeast Asian Studies 29 (2): 374-391.

Pelley, P.M. 2002. Postcolonial Vietnam: New histories of the national past. Durham, NC: Duke University Press.

Purushotam, N. 2000. Negotiating multiculturalism: Disciplining difference in Singapore. Berlin: Walter de Gruyter. 
Rabinow, P. 2002. French DNA: Trouble in purgatory. Chicago: University of Chicago Press.

Rajan, K.S. 2006. Biocapital: The constitution of postgenomic life. Durham, NC: Duke University Press.

Reardon, J. 2009. Race to the finish: Identity and governance in an age of genomics. Princeton: Princeton University Press.

Rudolph, J. 1998. Reconstructing collective identities: The Babas of Singapore. Journal of Contemporary Asia 28 (2): 203-232.

Saigoneer. 2019, July 22. Ancient Kinh Vietnamese might hail from Africa instead of China, Genome Project Shows. https://saigoneer.com/vietnam-news/16980-ancient-kinh-vietnamese-might-hail-fromafrica-instead-of-china,-genome-project-shows. Accessed 18 Nov 2020.

Sleeboom-Faulkner, M. 2006. How to define a population: Cultural politics and population genetics in the People's Republic of China and the Republic of China. BioSocieties 1 (4): 399-419.

Sun, S. 2017. Socio-economics of personalized medicine in Asia. London: Routledge.

Sung, W.C. 2010. Chinese DNA: Genomics and bionation. In Asian biotech, 263-292. Durham, NC: Duke University Press.

Tan, E.K. 2003O. Re-engaging Chineseness: Political, economic and cultural imperatives of nation-building in Singapore. The China Quarterly 175: 751-774.

Taylor, K.W. 2013. A history of the Vietnamese. Cambridge: Cambridge University Press.

Teoh, K.M., (2015). Domesticating hybridity: Straits Chinese cultural heritage projects in Malaysia and Singapore. Cross-Currents: East Asian History and Culture Review, 1(17), 58-85.

Thayer, C.A. 2002. Vietnam in 2001: The ninth party congress and after. Asian Survey 42 (1): 81-89.

Thompson, C. 2010. Asian regeneration? Nationalism and internationalism in stem cell. In Asian biotech: Ethics and communities of fate, 95. Durham, NC: Duke University Press.

Thompson, C.M. 2003. Medicine, nationalism, and revolution in Vietnam: The roots of a medical collaboration to 1945. East Asian Science, Technology, and Medicine 21 (1): 114-148.

Tran, N.B. 2018. Viện BigData của Vingroup: Làm vì sĩ diện của người Việt. Báo điện tủ [Translated as: VinGroup's Big Data Institute: For the pride of the Vietnamese]. VTC News. https://vtc.vn/vienbigdata-cua-vingroup-lam-vi-si-dien-cua-nguoi-viet-ar421808.html. Accessed 12 Apr 2019.

Tsai, Y.Y. 2010. Geneticizing Ethnicity: A study on the "Taiwan Bio-Bank." East Asian Science, Technology and Society: An International Journal 4 (3): 433-455.

Tsai, Y.Y., and W.J. Lee. 2020. An imagined future community: Taiwan Biobank, Taiwanese genome, and nation-building. BioSocieties. https://doi.org/10.1057/s41292-019-00179-z.

Tupasela, A. 2017. Populations as brands in medical research: Placing genes on the global genetic atlas. BioSocieties 12 (1): 47-65.

Tupasela, A., and K. Snell. 2015. Constructing populations in biobanking. Life Sciences, Society and Policy 11 (1): 1-18.

Turnbull, C.M. 2009. A history of modern Singapore, 1819-2005. Singapore: NUS Press.

Van Epps, H.L. 2006. Singapore's multibillion dollar gamble. The Journal of Experimental Medicine 203 (5): 1139 .

Vietnam Briefing. 2019. Vietnam's New Incentives for Science and Technology Firms. https://www.vietn am-briefing.com/news/vietnam-new-incentives-for-science-and-technology-firms.html/.

Wade, P. 2017. Degrees of mixture, degrees of freedom: Genomics, multiculturalism, and race in Latin America. Durham, NC: Duke University Press.

Wade, P., C.L. Beltrán, E. Restrepo, and R.V. Santos, eds. 2014. Mestizo genomics: Race mixture, nation, and science in Latin America. Durham, NC: Duke University Press.

Waldby, C. 2009. Singapore Biopolis: Bare life in the city-state. East Asian Science, Technology and Society 3 (2-3): 367-383.

Whitmarsh, I. 2009. Hyperdiagnostics: Postcolonial utopics of race-based biomedicine. Medical Anthropology 28 (3): 285-315.

Winichakul, T. 1997. Siam mapped: A history of the geo-body of a nation. Honolulu: University of Hawaii Press.

Wu, D., J. Dou, X. Chai, C. Bellis, A. Wilm, C.C. Shih, et al. 2019. Large-scale whole-genome sequencing of three diverse Asian populations in Singapore. Cell 179 (3): 736-749. 
Publisher's Note Springer Nature remains neutral with regard to jurisdictional claims in published maps and institutional affiliations.

Tiên-Dung Hà PhD student, Department of Anthropology, Stanford University.

Mohammad Khamsya Bin Khidzer PhD Candidate, Department of Sociology and Science Studies, University of California, San Diego. 